\title{
(In Press)
}

\author{
Forthcoming in
}

GLOBALIZATIONS 16 (4) June 2019.

\section{The Global Subject of Precarity}

\author{
By \\ Ritu Vij \\ University of Aberdeen
}

\begin{abstract}
This article explores the universalizing logic of precarity and precariousness in global studies discourse. Originally articulated in the work of Guy Standing and Judith Butler, this logic presupposes a possibility for a global politics of equality between precarious subjects in the North and South based on an emergent shared horizon of suffering. In a close reading of Standing and Butler, I challenge claims about equivalence by calling attention to the liberal analytics that inform their work. Drawing on a postcolonial attunement to historically constituted exclusions, I argue that precarity is better understood as a dis-ordering experience of sovereign subjectivity whose principal referent is the liberal not global subject of precarity. Globalizing the liberal subject of precarity entails the recuperation of its constitutive outside, namely the Third World, as the original site of abjection. The de-politicizing implications of attempts to universalize the subject of precarity are briefly outlined in conclusion.
\end{abstract}

\section{Introduction $^{1}$}

This article explores the universalizing logic of precarity and precariousness in global studies discourse. Originally articulated in the work of Guy Standing and Judith Butler, this logic presupposes a possibility for a global politics of equality between precarious subjects in the North and South based on an emergent shared horizon of suffering. In a close reading of Standing and Butler, I challenge claims about equivalence by calling attention to the liberal analytics that inform their work. Drawing on a postcolonial attunement to historically constituted exclusions, I argue that precarity is better understood as a dis-ordering experience of sovereign subjectivity whose principal referent is the liberal not global subject of precarity. Globalizing the liberal subject of precarity 
entails the recuperation of its constitutive outside, namely the Third World, as the original site of abjection. The de-politicizing implications of attempts to universalize the subject of precarity are briefly outlined in conclusion.

In a widely cited essay, 'Choosing Precarity,' the noted critic Simon During suggests that modes of contemporary dispossession may be better apprehended through the concept and discourse of precarity, a term whose expansive epistemic reach invokes "the insecurity of all those who live without reliable and adequate income or without papers, as well as those with no, or unstable, access to the institutions and communities best able to provide legitimacy, recognition and solidarity" (During 2015, 58). The precariat, he notes, is "a global group that includes people from many classes, religions and cultures," whose "subjectivity becomes increasingly exposed to serious, restless, and vulnerable contextlessness" (During 2015, 59). Central to the passage to precarity is, During suggests, the displacement of one background anthropology by another, specifically an anthropology of lack in which vulnerability, uneasiness and instability are recognized as fundamental to an (originally Christian) understanding of human nature. In a reading of Amit Chaudhuri's novel, The Immortals, that concludes his argument, During finds the novel's protagonist Nirmalya's decision to 'choose poverty' in London over the comfort of a middle-class existence in Bombay an instance of an affirmative precarity, a choice of a secularized anthropology of negation. Wrought within a uniform temporal horizon (of neoliberal capital time), and inhabiting a similar anthropology of lack, precarity as a global condition brings into equivalence subjects in the Global North and South.

During's argument joins a growing trans-disciplinary discourse on the universal logic of precarity and precarization (Barchiesi 2011; Bernards 2018; Breman and van der Linden 2014; Comaroff and Comaroff 2012; Ettlinger 2007; Lorey 2011; 2015; Pang 2018; Trott 2014; van der Linden 2014; van der Linden and Roth 2014; Waite 2009). Contemporary thinking on precarity and precarisation as universalizing concepts subsumes previous formulations of precarity as principally the insecuritization of waged work in the Global North catalysed by the depredations of neoliberal economic globalization and the dismantling of the Keynesian social compact (Neilson and Rossiter 2008). Insecure, contingent and informal unwaged labour, once the hallmark of underdevelopment in the Global South, but now increasingly visible in the hinterlands of want amidst wealth in the Global North, summons a mode of thinking that posits a global (neoliberal) logic and ontology of precarity's socio-economic form beyond labor contingency (Lorey, 2011; 2015; Barchiesi 2011). For some, the subject of precarity is a globalized subject given the prevailing neoliberal logics of governing that necessitate practices of insecuritization as a (Foucauldian) biopolitical technology of rule (Lorey 2011; 2015), a practice of global governance (Bernards 2018), or a source of 'political 
subjection' (Lazzarato 2017). As a structure of feeling occasioned by the loss of futurity (Foti 2017) or 'cruel optimism' (Berlant 2011), an attachment to a condition of loss, precarity indexes the antinomies of an ongoing global present. For labor historians and sociologists work insecurity stems from the informalisation of production inaugurated by financialized neoliberalism and globalization (Van der Linden 2014; van der Linden and Roth 2014; Brass 2011; Bourdieu 1998; Beck 2000). For political theologians, financialization itself (and its associated depredations) is symptomatic of a 'meta-crisis of secular capitalism' (Milbank and Pabst 2015). On an alternative critical register, neoliberal globalization generates logics of dispossession (Harvey 1982; 2004), expulsion (Sassen 2014), primitive accumulation (Perelman 2000), or 'aleatory capitalism' (Read 2002) that flatten the texture of the social fabric as violent processes of market dis-embedding (Polanyi 1957) create 'surplus populations,' sites of abandonment (Povinelli 2011) and abjection ${ }^{2}$ (Kristeva 1982), subject to forms of slow violence (Nixon 2011). ${ }^{3}$

Guy Standing's The Precariat: The New Dangerous Class (2011) and Judith Butler's Precarious Life: The Powers of Mourning and Violence (2004), however, are widely seen as the key texts to apprehending the subject of precarity in global terms. Standing anchors precarity in a sociological analysis of labor contingency in which work and employment related uncertainties spill over into socio-cultural-psychological insecurities. As labor supply chains connect multinationals to an everready supply of cheap labour, the depression of wages globally conjoined with austerity and increased competitiveness causes a race to the bottom as rising levels of unemployment are exacerbated by the worsening of conditions for labor. The 'global precariat,' composed of precarious workers, but predominantly migrants, asylum seekers and refugees are subjected to a range of insecurities that produce 'precaritized minds' and the negative affects that characterize them, including anomie, alienation, and the loss of dignity that comes with heightened dependency on others. In a follow up text, A Precariat Charter: From Denizens to Citizens (2014), a manifesto of 29 rights for the global precariat, Standing notes: "Knowing that your fellow citizen has the same rights as you do humanises us all" (Standing 2014, 379).

On a different register, Butler's concept of ontological precariousness as an existential condition appears to render the claim about a global subject of precarity incontrovertible. Foregrounding the contingency of life and the awareness of co-vulnerability, Butler's Levinasian ontology of relationality renders the recognition of all life as precarious. While this post-foundational account of the nonsovereign ${ }^{4}$ subject is supplemented by a recognition of the hierarchies of socio-economic 'precaritization' that make some more vulnerable than others, Butler's socio-economic register of distinctions does not vitiate the claim about the universality of ontological precariousness. Like 
During's appeal to a philosophical anthropology as the ground of a globally induced condition of vulnerability, Butler's ethico-ontological turn conjoins the socio-economic-affective register of precarity talk with the philosophical for an attunement to a decidedly global precarity. For both, During and Butler, precarity and precariousness lead us to recognize and accede to an account of what it is to be human and the vulnerability attached to life and living itself; for Standing, guaranteeing the rights of all, denizens and citizens, humanises all.

Insecurity, uncertainty, contingency, and dependency, however, are not novel conditions but integral to both life and living at all times and places. Unemployment, informal work, the constant (re)production of a reserve army of labor, extremes of wealth and want, migration and refugees have been part of the international landscape for at least as long as capitalism and the system of states have been consolidated. And recognition of our ontological vulnerability as a species, i.e. the facticity of our primal dependency on others, is also not new but indeed central to moral philosophy in western and non-western genres of humanist thought.

Why then the heightened anxieties that have mobilized a discourse constituting the subject of precarity as global? What might critical International Relations (IR) attentive to the occlusion of difference in the constitution of the international bring to our understanding of precarity/precariousness and the antagonisms contained (and repressed) in the figure of a global subject of precarity? What is at stake, theoretically and politically, in the concept of a global subject of precarity?

In a departure from established conventions of critique in the literature on global precarity, this article draws attention to precarity as principally a liberal analytic, tethered to and framed by liberal accounts of the sovereign subject. Concepts of precarity and ontological precariousness gain traction, I argue, only in reference to the regulative ideal of self-mastery, autonomy, futurity and the expectational horizon of an invulnerability to insecurity that is central to western capitalist modernity. The "subject of security is the subject of security," R.B.J. Walker writes, "....... predicated on the impossible dream of absolute invulnerability," where "modern accounts of security are precisely about subjectivity, subjection and the conditions under which we have been constructed as subjects" (Walker 1997, 71-78). This subject is the liberal subject of security, forged and sustained within a specific (unequal) ordering of the modern international: wealth and security inside liberal, modern, democratic states; poverty and insecurity outside - in 'illiberal,' 'traditional,' 'backward' states. Taking this insight from critical IR as a point of departure brings a new angle of vision to debates about the analytical reach of precarity/precariousness. I argue here that precarity as exposure to vulnerability is the spectre that haunts the liberal subject of security. Precarity is thus 
better understood not as a globally dispersed socio-economic positivity but as a dis-ordering experience of sovereign subjectivity, a breach of the regulative ideal and anthropology of selfmastery, whose principal referent is the liberal not global subject of security.

Extended globally, however, global 'precarity talk'5 (Puar 2012) enacts a double erasure obscuring : (1) the sedimentations of colonial history that have rendered the Third World the constitutive outside of the liberal/modern international, shaping distinctions between the sovereign subject of western liberal modernity and its non-sovereign, illiberal other; and (2) the political-economy of colonial difference that has rendered Third World 'backwardness' the pathologized container of material lack, dependency, and abjection. Globalizing the subject of precarity thus entails the recuperation of the Third World as a site of abjection.

The entangled histories of imperial violence, slavery, and colonial conquest suppressed in global precarity talk return, albeit surreptitiously, to anchor claims about the global subject of precarity. The denial of coevalness, central to demarcating socio-cultural-economic distinctions between the west and the rest (Fabian 1983), is reversed in global precarity talk as a common horizon of suffering in the neoliberal present seemingly brings into equivalence those in the North and the South. Paradoxically, however, this reversal of the denial of coevalness does not translate into equivalence: within a quantified comparative register (more or less precaritization), abjection in the Global South remains the yardstick against which well-being (and now suffering) in the North continues to be measured. Forms of life (mis)construed as abjected on this quantified evaluative register remain outside the bounds of liberal recognition as otherness is converted into sameness.

For the majority of the world's population inhabiting modes of life in which uncertainty/contingency is anchored in and sustained by alternative ontological landscapes and the multiple temporalities constitutive of them, however, life is not simply abject but "waxes and wanes" at different "thresholds of life" and intensity (Singh 2015) that are material but also spiritual, cultural and aesthetic. By enclosing quotidian de-pathologized modes of life in what Sherry Ortner (2016) describes as a 'dark anthropology' of dispossession, vulnerability, and precarity, contemporary discourse on the global subject of precarity forecloses recognition of alterity. The subject of precariousness is the modern subject of security, globalized only at the risk of writing out of contemporary history subjectivities and lives lived in modes of de-pathologized vulnerability in much of the world. Reading precarity/precariousness as liberal discourse unsettles the pathologization of vulnerability as a global condition; it also opens up pathways to recognizing ontological difference in modes of life and living in de-pathologized vulnerability for the majority of the world's population. 
The argument proceeds in three steps: (1) the first section interrogates accounts of precarity writ large, focussing especially on Guy Standing's work, to show how the (liberal) anxieties that frame global precarity talk depend on and mobilize long standing tropes about abjected modes of life in the Global South to ground its key claims. My argument - that precarity is a liberal not global analytic - supplements extant modes of critique anchored in Marxian, biopolitical or global development approaches (Agathangelou and Weber, this issue), but moves the conversation in a different direction. (2) The second section explores some antinomies in Judith Butler's notion of ontological precariousness as it relates to claims about the unequal distribution of precaritization; the liberal subject, undone by the former, returns in the latter as a default liberal analytic of quantification (more or less precaritization) that unwittingly renders vulnerabilities in the South abject.

Repudiating the continued abjection of the South in the false equivalence posited in global precarity talk, I conclude by sketching an alternative approach to thinking precarity qua vulnerability in a global context, briefly returning to Amit Chaudhuri's The Immortals (2009) to illustrate my argument.

\section{Precarity as a Liberal Analytic}

"We're all precarious now," declares a headline in Jacobin Magazine, capturing the zeitgeist of the contemporary moment. Academic debates about the reasons for the globalization of precarity have been fierce and are well documented in the literature ${ }^{6}$. Broadly speaking, the claim about a globally dispersed worker precariousness is tied to financialized neoliberalism, the rise of automation and austerity (especially in the wake of the 2008 financial crisis). The decline of manufacturing in the advanced capitalist economies and the worldwide depression of wages in the North due to the addition in the global workforce of workers from the South (China and India) willing to work for lower wages is also seen as pivotal to worker precariousness in the North. The iconic text in these debates, Guy Standing's The Precariat: The New Dangerous Class (2011), especially, has been the subject of intense criticism (Breman 2013; Munck 2013; Scully 2016; Seymour 2012) for eliding the class aspects of precarity, including its propensity to generate a reserve army of labor, surplus populations, and disposable lives. For these critics, precarity is at best a descriptive classification of labor stratification (revealing the text's hidden attachment to the labourism it otherwise excoriates), or worse a "bogus concept" (Breman 2013). For others, growth in working-class precariousness is the movement "toward de-proletarianization rather than toward proletarian unification" (Wacquant 2007). I will not rehearse this debate here since my purpose is to bring into visibility a feature of global precarity talk that has thus far escaped critical scrutiny: grasped as a form of Northern theory (Connell 2007), global precarity talk registers a latent anxiety about the movement from secure to insecure work that unsettles the liberal, sovereign subject. It is this anxiety that both reinscribes 
abjection in the South and misconstrues the phenomenology of precarity there while claiming a false equivalence between precarised subjects in the North and South.

Claims about worker precarity as a global condition typically deploy empirical data to make their case. I begin, then, with a brief look at data on the global distribution of precarious work to contextualize the discussion that follows. Re-categorized as 'irregular work,' in contrast to 'decent' work, by the International Labor Organization (ILO hereafter), Guy Standing's former employer and the principal global institution responsible for tracking (and governing) precarious work, the data on 'irregular work' tell an interesting story. Stretched globally, the absence of 'decent work' marks the point of departure for thinking the subject of precarity in global terms. The ILO's most recent report on irregular work, Non Standard Employment around the World: Understanding, Challenging, Shaping Prospects (ILO 2016), documents the rising instance of temporary employment in 150 countries. Benchmarked against the norm of 'decent work' (work that is full time, indefinite), irregular work comprises $5 \%$ of the waged work-force in countries like Jordan, Latvia and Norway, but 25\% in Mongolia, Peru and Spain; two-thirds of workers in Bangladesh and India, however, are in causal work. In the advanced capitalist economies, on the other hand, insecure and contingent work for people on zero-hour contracts made up $2.5 \%$ of the work force in the UK and $10 \%$ in the USA at the end of 2015. Similarly, the ILO's 2018 report, Women and Men in the Informal Economy: A Statistical Picture, points to the big difference in the size of the informal sector in the North and South: the total share of informal employment in total employment is $18.1 \%$ in North America compared to $87.8 \%$ in Southern Asia (with a larger component of informal employment in the informal sector for both). In the cold, harsh light of this comparison, the ILO's adoption (Recommendation No. 204, 2015) to achieve 'decent work for all' can be read as phantasmatic, applicable perhaps to the relatively small informal sector in the Global North, but not the South where the sheer scale of the problem ( $88 \%$ in the informal sector in the case of India) defies any realistic scenario of a transition to 'decent work' (Doogan 2009; Munck 2013).

Given the magnitude of difference in the extent of 'irregular work' in the North and South, the claim to equivalence is, at the very least, puzzling. Standing's analysis begins with an almost exclusive focus on labour conditions in the North and the (comparatively small) rise in precarious work (as documented above) before moving to claim that the North's proximity to the South in terms of the (falling) conditions of labour warrants recognition of a novel condition of globalized precarity. The bulk of Standing's text, The Precariat, is devoted to making the case for the emergence of a "new class system" in reference to Europe and North America (with some scattered reference to Japan) (see also, Standing 2012; 2013). This new class system is made up of (in descending order), a rentier 
class of the elite, the salariat with employment security, proficians (making money but without security of employment), the old working class- proletariat, the precariat, and the unemployed. The precariat as a new "global class" is defined by labor contingency, but "most significantly by the absence of an occupational identity or a narrative to give to their lives which creates existential insecurity" (Standing 2011, 24). Reliant exclusively on money wages, without non-wage or rightsbased state benefits, the "precaritised mind" (Standing 2011, 18-19) is highly anxious, reduced to being supplicants, asking "for favours, for charity, to show obsequiousness, to plead with figures of authority. It is degrading and stigmatizing" (Standing 2016). Finally, "the precariat have a weakened sense of "social memory.... relational and peer-group interaction.... no sense of career, secure occupational identity, few, if any entitlements to the state and enterprise benefits" (Standing 2011, $23-24)$.

Given the centrality of work, property and possession to (the constitution of) personhood in western modernity - the condition of possibility for autonomy for Kant or subjective freedom for Hegel - the loss of occupational identity can indeed be tantamount to loss of self and the onset of ontological insecurity. Work (or more precisely work as labor that is remunerated) and its corollary, a workethic (Weeks 2011), is central not only to economy and ethical being but also to subjective identity. Understood both as an internalized social norm and the locus of self-making (as the negation of one's natural or determinate condition), work as labour can be seen as pivotal to western ontology, it's absence or loss designating pathologized lack, or, worst, dependency". Without "the mediation of work", (Hegel [1820] 1991, 267), in a capitalist social context where quantitative hierarchies of wealth and want measure self and social worth, subjectivity and well-being are put into jeopardy. The precarious here join the ranks of the "undeserving poor," their material lack evidence of the lack of personal or social self-worth.

To be sure, Standing himself does not ground his discussion of precarity in the context of what I am calling (following During) the background anthropology of precarity's provenance in the North. But, as I argue below, precarity's (restricted) epistemic reach comes fully into view only in the context of its background anthropology. As a description of the precarious subject in the Global North, Standing's account may withstand scrutiny: within a normative horizon in which the regulative ideals of self-reliance, autonomy, and work-centered subjectivity are dominant, the negative affect generated by the loss of work may well be severe. However, worst by far in Standing's reading of the pathology of precarity is the loss of futurity that creates a precaritised mind, reducing precarious subjects to "supplicancy and dependency which is degrading and stigmatizing" (Standing 2016). Rather than instantiating a universal relation to time, the notion of the loss of futurity gains salience 
in the context of a specifically western ontology. Every ontology "has a particular regime of temporality" Phillipe Descola notes, "and only the ontology of the West is marked by an "onward" arrow of time, an endless progress!" (Descola, 2017; see also Holbraard and Morten 2017). Supplicancy and dependency, disavowed in (hegemonic) western thought as hallmarks of the absence of 'maturity' of the liberal subject (rational, autonomous, sovereign) turn out to be the affective axis around which the latent anxiety about the insecuritization of work turns. Standing's conceptualization of precarity, in other words, and its attendant phenomenological and affective attributes can be clearly seen as anchored in a particular (liberal) notion of the subject. Globalizing the subject of precarity thus presupposes the universalization of the liberal subject, and the concomitant erasure of pre/proto capitalist zones of life. The (liberal) violence produced by modernization/developmental projects devoted to fashioning precisely such subjects in the South serve as a cautionary note against such civilizing missions in the present conjuncture.

But Standing does not stop at the borders of Euro-America. Devoting the first half of The Precariat to elaborating his concept of precarity and detailing the reasons for its growth, Standing anchors his account firmly in the conditions of work insecuritization in the North (Britain, Italy, France, the USA, and a brief discussion of Japan, also an OECD country). Having done that, however, chapter 4 goes on to declare that there is, in fact, a 'global precariat ${ }^{8 \prime}$ (Standing 2011, 111) but now made up largely of migrants and refugees documented and undocumented, a "floating reserve" army of global labor that constitutes the bulk of the precariat. The majority of immigrants are, by Standing's reckoning, from poor countries, making the 'global precariat' largely composed of people from formerly colonized areas: Asia, Africa, and the Middle East. By way of example, a quick look at international migration statistics from the Migration Policy Institute confirms that among the top 25 countries by destination of refugee populations as a share of the total population, nearly all were of the Global South with the Palestinian Territories (43\%), Jordan (30\%) and Lebanon (25\%) at the top of the list; Germany, the only Northern country on the list took in refugees equivalent to $1.5 \%$ of its total population. Pakistan, Jordan, Uganda, all three 'developing' countries took in 1 million asylum seekers, the same as Germany. That South-South migration overwhelms South-North flows is evident even from this cursory look at the figures. That most migrants, refugees and asylum seekers are not moving from secure to insecure work is, arguably, also clear. That 'migrants' and refugees' lives are subject to uncertainty, insecurity, and unpredictability is indisputable but on a purely descriptive level. Analytically, on Standing's terms, precarity entails labor contingency but also, among other things, "the loss of occupational identity.....a weakened sense of 'social memory'.... relational and peer-group interaction... no sense of career, secure occupational identity, few, if any entitlements to the state and enterprise benefits" (Standing 2011, 23 -24), a description that rings 
hollow for the vast majority of people in the South doing insecure work or caught up in the maelstrom of civil strife or war that has created the contemporary migrant/refugee crisis for Northern states. Dependency on others, anathema to precarious subjects in the North is, in fact, axiomatic to life in the South, particularly for populations with limited access to material resources.

Why then Standing's compulsion to claim migrants, refugees and asylum seekers as exemplary, central to his claim that the precariat is indeed a global precariat? Standing's position is that global migration (documented or otherwise) is subject to capture analytically since it only requires the extension of the concept of precarity to a global register, even though the bulk of migrant populations do not meet the criteria Standing elaborates in his concept of precarity. Described in anecdotal rather than statistical terms, the migrant/asylum-seeker/refugee's life is, on Standing's terms, wretched, dismal, abject. Described as living in squalid conditions in makeshift encampments across Europe (including Italy, Germany and Sweden), not to mention internal migrants in China and India, the migrant as precariat exemplar is, however, I want to suggest, essential, not supplementary, to Standing's case. Rather than an empirical instantiation of Standing's concept of precarity, the figure of the abjected migrant/refugee/asylum seeker performs a vital function in Standing's precarity talk.

Seen within the context of the long durée, precarity as a liberal analytic of the internal Other is premised on a prior Other-the non-Western 'Third World' as its constitutive condition of possibility. As the container for disavowed attributes of the (liberal) Self: immaturity, backwardness, religiosity, but above all, material 'lack' and poverty, the South as an 'ex-centric' (Bhabha 1994) dystopian zone of abjection ${ }^{9}$ has been central to the boundary making practices constitutive of the modern international. Temporal and cultural non-equivalence between the advanced North and the 'backward' South, between wealth in one and poverty in the other has been key to establishing distinctions between the west and it constitutive outside. Global precarity talk ostensibly undoes this distinction, foregrounding a now putatively common horizon of suffering. However, in claiming a common condition of insecurity, global precarity talk universalizes an abjection previously located in the Third World. The compulsion to globalize the subject of precarity can arguably be seen as logically necessary: vulnerability, poverty, material lack, disavowed and located in the Third World, can be recuperated in precarity talk only by laying claim to a form of life it has itself construed as abject. The South as a place of desperate poverty, destitution and lumpen life-worlds retains its hold in the social imaginary as equivalence is dirempted into its opposite. The West's use of the East to tell stories about "itself to itself" (Gregory 2004, 4) has been called out by postcolonial thought in the last many decades. That it continues to frame arguments ostensibly devoted to un-doing 
hierarchies of wealth and want between the North and South is testimony to its intractability. "Africa", Achille Membe writes, "is the mediation that enables the West to accede to its own subconscious and give a public account of its subjectivity" (Membe 2010, 3). Abjection in the South, recuperated in the figure of the migrant, enables, we might say, a transfer of abjection from the South to the North in a move that augments the dystopic depiction of the precariat. Parallel to that, and more poignantly I want to suggest here, the South retains its imputed position as the locus of abjection. Colonial imaginaries are re-inscribed yet again in claims about (false) equivalence between precarious subjects in the North and South. Seen in this light, there can be no conceptual straight lines that can be drawn "from the colonial slum to the cosmopolitan precariat" (Lawn 2017); nor can the vast swathes of humanity that make up the informal sector or the lumpen-proletariat in the Global South be seen simply as an instantiation of precarity in the south (Munck 2013), or as precursors to precarity in the North (Han 2018).

Sedimented colonial imaginaries remain entrenched in efforts to think the ongoing global present in popular titles like Third World America (Huffington 2010) and other academic work. Two brief examples help to register the ubiquity of such moves. Ulrich Beck's notion of the 'Brazilianization of the West' (Beck 2000, 1) is particularly apt. Grounding the globalization of precarity in the spread of "neoliberal free-market utopia" (Beck 2000, 1) Beck draws attention to the deterioration of work conditions and the heightened risk that insecuritization of work brings to European societies. As work relations in the North are de-regulated and flexibilized, the West comes to resemble, he notes, the "patchwork quilt of the South, characterised by diversity, unclarity and insecurity in people's work and life" (Beck 2001, 1). Brazilianization here connotes the turn to "informal, nomadic multiactivity work," typically associated with countries of so-called "pre-modernity" (Beck 2000, 93). In a move intended to convey self-irony, he goes on to note "it may be said that the Brazilianization thesis does appear at first sight to renew, through negative immersion, the romantic image that Westerners tend to have of Brazil" (Beck 2000,93). However, lest the reader make the error of collapsing historical and cultural differences between Brazil and the West, he clarifies what he means by the term: "what appears the same means in Europe the erosion of labour rights, living standards and social security" (Beck 2001, 96). "The theorem of Brazilianization is beyond either universalism or relativism!" (Beck 2001, 96). We can marvel at the sentiment expressed here as we note that slouching from Europe to Brazil is a journey of lament as 'our' collective (European) descent into a society of risk entails also an act of re-naming: Europe no more, now Brazil. Colonial distinctions, cultural, historical, economic are, it seems, hard-wired in time. 
Jean and John Comaroff's provocation in Theory from the South (2012), that "Euro America is evolving toward Africa" is metonymic of the trend in scholarship to lay claim to a more radical, cosmopolitan and inclusive equivalence between North and South. Ironic, even playful, the book's attempt to move beyond mere coevalness to turn Eurocentric modernization theory upside down, by locating a Euro-American future in Africa's present in all its fractured intensities is especially instructive for our purposes here. Arguing that Africa (a stand-in for the South) is the site of innovation (in finance, social policy, slum re-development) at a time when advanced capitalist societies in the North are hard pressed to find solutions, the Comaroffs in an effort to move beyond Fabian's critique of the denial of coevalness end up, inadvertently and despite their stated intent, in reinscribing it. Africa is 'ahead' in that it provides an 'advanced face' of the "hydra-headed configurations of contemporary capitalism" (Comaroff and Comaroff 2012) and its itineraries of socio-economic lack: "material inequality, human disposability, epidemic illness, social exclusion" (Comaroff and Comaroff 2012). Despite their partially parodic, "counter-evolutionary" perspective that attempts to reverse Hegelian teleology and turn epistemological racism on its head (Africa leads, Euro-America lags), the Comaroffs unwittingly tap into an imagery of Africa they intellectually and politically reject. Srinivas Aravamudan's wry observation to the Comaroffs makes the point well: "Africa is ahead, not because it is more enlightened in classical terms; it is ahead because it is more familiar with.....urban blight, the genocidal epidemic of HIV-AIDS," and because it is "the world's dark overlord, prescient of all things to come" (Aravamudan 2012). Structurally entrenched geocultural geo-epistemologies are not easily cast aside, the 'global subject of precarity,' its most recent instantiation.

Without recourse to the tired image of the Third World as a zone of abjection, global precarity has no independent locus. A putatively generous move ("we are all precarious now") ends up reinforcing the image of the Third World as a zone of abjection, now available to previously sovereign Western liberal subjects. By freezing historical time and its denial of coevalness, global precarity talk creates a unitary present that elides the historical shaping of hierarchies of wealth and want and the construction of the Third World as abject. Claiming common ground, however, does little to stop the echoes of earlier times. James Blaut's scathing account of "European diffusionism," where the "West has a permanent geographic center and a permanent periphery; an inside and an outside. Inside leads, Outside lags" (Blaut 1993, 1) still reverberates. Extending a predominantly liberal analytic of precarity globally entails a deft acrobatic move: Euro-American precarity appears to bring the outside in but Europe still 'leads' in its denial of radical alterity in the South. Modes of life in the South construed as abject in the modern international are, in fact, simply forms of life lived otherwise, alterities destined to remain forever beyond the grasp of the vocabulary of dominant 
strands of social thought, frozen in historical time as the permanent Outside of the liberal modern. The continued imbrication of liberal analytics with a denial of alterity remains in play, paradoxically as I show below, in work devoted to undoing the liberal subject as the condition of possibility for generating a transformative global ethics and politics.

\section{Ontological Precariousness: A Liberal Backstop?}

I have thus far argued that global precarity talk posits a non-equivalence at very heart of claims of equivalence between precarious subjects in the North and South: the South as the abjected other anchors and mobilizes a discourse about the globalized subject of precarity. I now turn to a critical exploration of Judith Butler's influential claim that ontological precariousness as the determinate condition of all subjects renders precarious subjects in North and South fundamentally equal in their common exposure to vulnerability. If we are all indeed equally precarious in our very existence as sentient beings, equivalence between subjects in the North and South is, quite literally, a fact of life. Recognition of this shared vulnerability as a fact of our common humanity can, Butler suggests, mobilize a transformative politics against the unequal distribution of socio-economic precaritization.

There is, of course, much that can be said about Butler's wide-ranging reflections (2001; 2004; 2005; $2009 ; 2013 ; 2015)$ on precariousness and precarity. In what follows, I draw attention only to those antinomies in her thought that unsettle claims about equivalence between precarious subjects in the North and South. My main aim is to show how Butler, her professed antipathy to liberal thought notwithstanding, retains a fidelity to a liberal analytic by (1) relying on a thin, quantitative notion of vulnerability that enables comparison (more or less precaritization) that unwittingly renders those at the lower end of the scale abject; (2) abstracting vulnerability such that it forecloses recognition of alterity. Modes of life deemed abject on a quantitative register of comparison are, in their alternative ontological and temporal habitations, simply quotidian. This line of critique goes some distance in enabling the recuperation of modes of life captured but misconstrued by global precarity talk as sites of abjection.

"I propose to start, and to end, with the question of the human (as if there were any other way for us to start and end!" (Butler 2004, 20) writes in response to the question of how to build community in the face of exposure to vulnerability and loss. Turning the question around she asks instead if common human vulnerability can become the basis for a new community. Her answer is unequivocal: ontological precariousness - the fact that we are all given over to the other due to a "primary vulnerability, a primary helplessness" - enables the recognition of all humans as equal and can therefore enable a transformative ethics and politics against precaritization. "Precariousness 
and precarity are intersecting concepts. Lives are by definition precarious: they can be expunged at will or by accident; their persistence is in no sense guaranteed" (Butler 2009, 25).

I do not mean to deny that vulnerability is differentiated, that it is allocated differentially across the globe.....I am referring to violence, vulnerability, and mourning, but there is a more general conception of the human with which I am trying to work here, one in which we are, from the start, given over to the other, one in which we are, from the start, even prior to individuation itself, by virtue of bodily requirements, given over to some set of primary others (Butler 2004, 30-31).

Precarity, however, designates that "politically induced condition in which certain populations suffer from failing social and economic networks of support and become differentially exposed to injury, violence, and death" (Butler 2009, 25). Whereas precariousness points to our common human vulnerability as the basis for a new community, the recognition of the vulnerability of only some renders the lives of others outside the social bond: "Is our capacity to mourn in global dimensions foreclosed precisely by the failure to conceive of \{some\} lives as lives? (Butler 2004, 12).

Drawing on Emmanuel Levinas' (1998) account of ethics as responsibility to the other, specifically his claim that "once one has truly encountered the other, it is impossible to do him (sic) harm," Butler outlines a social ontology of relationality that takes the primordial atemporal experience of the other as a way to understand the way in which all of us are already given over "not precisely bounded, not precisely separate, but in our skins, given over, in each other's hands, at each other's mercy" (Butler 2001, 39). Committed to unsettling the unitary account of the self-possessed sovereign subject of Enlightenment thought, Butler's Levinasian account of relationality acknowledges nonetheless that this primal dependence on the Other can provoke both the fear of undergoing violence and the fear of inflicting violence (Butler 2004, 37). However, the Hobbesian solution to the ambiguous provocations of ontological vulnerability, namely that we attempt to impose our vulnerability on others, is one that is not easily set aside. To resolve this dilemma, Butler turns to the role of recognition and norms such that more inclusionary norms based on the "insurrection at the level of ontology" (Butler 2004, 33) can foster an ethos of solidarity that would affirm mutual dependency.

Recognition of precariousness as a shared existential ontological condition (of Being) is construed as dependent on the resignification of norms that "have developed historically to maximize precariousness for some and minimize precariousness for others;" and further, "norms of recognition are essential to the constitution of vulnerability as the precondition of the 'human' 
(Butler 2004, 43). "The postulate of generalized precariousness which calls into question the ontology of individualism, implies though it does not directly entail, certain normative consequences" (Butler 2009, 33). These 'normative consequences,' Butler assumes, are potentially progressive: ontological precariousness, because equally shared by all, implies a radical equality. However, the uneven distribution of socio-economic-political precaritization and inequality raises a crucial question not directly addressed by Butler: by what measure do we apprehend equality in shared vulnerability and the unequal distribution of precarity?

On the above, highly compressed, summary of Butler's argument, ontological precariousness is the basis of an ethic of radical equality where the common horizon of a shared vulnerability is all encompassing, i.e. global. However, insofar as vulnerability can only be understood according to cultural and historical norms that recognize it as the precondition of the human, the measure by which we apprehend shared, i.e. equal, vulnerability and its unequal distribution across geographies, is crucial. If the resignification of norms of value and valuation (grievable and ungrievable lives) precedes recognition of our global humanity and efforts to build collective solidarities, by what measure are vulnerabilities apprehended in their (in) equality?

I will set aside here the fraught question of recognition and the trajectory of classical liberal thinking that places the idea of autonomy, self-mastery and sovereign subjectivity at its center but simply note that Butler's attempt to move the problem of recognition from an ontology of individualism to a Levinasian 'ontological claustrophobia' (Llewelyn 1995, 7-17), is not without its difficulties (see especially Alford 2002; Drabinski 2011; Gilson 2014; Lloyd 2015; Mills 2007; 2015; White 1999). Equally contentious is the question of resignifying exclusionary norms and their associated practices from a socio-historical field shaped by the ravages of colonialism, slavery, empire and capitalism, a question of politics not ethics. The Hobbesian dilemma, that shared vulnerability does not produce equality but more often the impulse to impose our vulnerability on others, renders a smooth passage from an ethics of equality to its socio-political instantiation fraught. A Butlerian response, satisfactory in its own way perhaps, would be that ontological precariousness offers a more promising pathway to building precisely such a collective project of a resignification of norms. But does it? And if so, what is the notion of equality that informs the presumed passage from ethics to politics?

Others have pointed out some of the problems contained in this circulatory logic, not the least of which have to do with the tenuous use Levinasian thought can provide to aid Butler's project (Alford 2002; Mills 2007; 2015; Tsantsoulas 2018). Three points are worth noting: (1) Levinas' commitment to the other is to the Otherness of the other (to the non-Being of Being in the cryptic 
language he uses), to Otherness as abstraction. The Levinasian self is held by this abstract (transcendent) otherness of non-being, a pre-ontic bond of relationality ("relation without relation" in Levinas' terms), apprehended 'at a distance' and not by virtue of the thickness of encounter with the other. This abstracted relation to otherness seeps into Butler's account as well and presses on her theoretical-political desire to think her way to recognition of a common or shared vulnerability ${ }^{10}$. (2) Levinas' argument about the "ambiguity of vulnerable embodiment" (it can invoke both a fear of violence and a fear of inflicting violence), undercuts Butler's attempt to construe the general condition of existential or ontological vulnerability in terms of equality; i.e. the link between ontological precariousness as a generalized condition of life as the basis of equality in Butler's formulation can be called into question. To sustain both claims (about the equality of ontological precariousness and the Levinasian ambiguity that shadows it), Butler needs to "view equality as a quantitative descriptor only" (Tsantsoulas 2018, 164), one that can "provide the ground for objecting to the differential allocation of precarity but only on the thin basis that it is quantitatively unequal" (Tsantsoulas 2018, 164). (3) Insofar as (1) and (2) hold, vulnerability is both construed as abstraction, as a generalizable and equally shared form of life, but also subject to measure, by virtue of this abstraction, on a thin quantitative register of more or less precaritization of the same.

It is this de facto resort to an abstracted, thin, quantified comparative register of measuring the unequal distribution of socio-economic-political precaritization that reveals Butler's unwitting fidelity to a principally liberal analytic. Insofar as western capitalist modernity reduces all qualitative differences to mere distinctions, a measure of different quantities of the same matter, Butler's implicit measure of unequal precaritization depends on a measure of value and valuation that cannot apprehend (qualitative) differences in the domain of vulnerability itself. Vulnerabilities, because measured on an identical quantified register can only yield a comparative valuation: those at one end marked by wealth and security, those at the other end by deprivation and lack. Recognition that those placed at the lowest end of a quantified comparative scale may not be abject but simply inhabiting "low consuming modes of life" (Nandy 2001, 11) that are quotidian, i.e. not pathological, is foreclosed in a liberal analytic of quantification. Quantification registers distinctions but distinctions that are without difference. Outlining the connection between vulnerability and the quantified register by which its unequal distribution is implicitly measured in her account enables Butler's unwitting (default) attachment to a liberal analytic to come into view.

In this context, it may be useful to briefly consider Butler's description of precaritization to see its affinities as a liberal analytic with Standing's. For both, the substantive features of precaritization relate quite candidly to the liberal subject whose natural habitat historically has always been in the North. Precaritization, a politically induced condition for Butler is the process 
of acclimating a population to insecurity. It operates to expose a targeted demographic to unemployment or to radically unpredictable swings between employment and unemployment, producing poverty and insecurity about an economic future, but also interpellating that population as expendable, if not fully abandoned. These affective registers of precaritization include the lived feeling of precariousness, which can be articulated with a damaged sense of future and a heightened sense of anxiety about issues like illness and mortality (especially when there is no health insurance or when conditions of labor and accelerated anxiety converge to debilitate the body) (Butler and Athanasiou 2013, 43).

Consistent with my argument that precarity gains traction only in reference to the liberal subject, specifically its move from security to insecurity, Butler's tracking of precaritization (and distinctions in the quantum of its provision on varied counts), with the move from security to insecurity brings its underlying liberal affinities more sharply into view. A pre-ontic relationality dispossesses sovereign subjectivity; dispossession within the domains of political-economy/political sociology on the other hand indexes the material and affective losses attendant on the move from security to precarity. On a quantitative measure, however, vulnerabilities at the lowest end of the scale are necessarily construed as abject, recognition of their radical alterities foreclosed by the use of a quantified metric of more or less vulnerability. Where the liberal subject (unitary or de-constructed) is taken to be the unexamined norm against which vulnerability is measured, those at the bottom of the scale can only be seen as abject.

For the vast majority of populations in the Global South, however, living within alternative ontological landscapes (albeit mediated by capital), contingency/ uncertainty/ lack of futurity and vulnerability may not be a disordering experience that disrupts the linear chronology of pastpresent-future within a temporal horizon framed by the expectation of an invulnerability to insecurity, what Peter Sloterdijk (2013) excoriates as "the expectation of security without struggle." Nor is it the 'norm' against which precarity as a new exception in the North is counterposed. It is rather a moment in a different ontological landscape in which vulnerability is not marked as a pathologized condition of lack but is simply life qua Being. Unlike the fear of vulnerability that predicates the discourse and affect of precarity in the 'west,' the seemingly normalized embrace of 'risk' and 'vulnerability' in the Global South marks not just fatalistic surrender to structurally produced inequities of wealth and want, but rather, and this is my point here, the mobilization of a vast repertoire of cultural, spiritual and social resources and the multiple temporalities contained therein, that enable modes of life and living that abjure vulnerability as abjection. Contrary to the "dark anthropology" of vulnerability and precarity that remains sutured to and informed by 
underlying regulative ideals of self-mastery and security, 'vulnerability' in the Global South paradoxically yields a more affirmative response, one structured by subaltern aspiration rather than despair. This aspiration, however, is not to enter the hallowed portals of liberal sovereignty and its horizon of expectation of becoming inured to insecurity. The deep structures of socio-affective ties that bind populations in putatively abjected zones in relational dependencies are not merely preontic but pivotal to life and living. Optimism is rendered 'cruel' (Berlant 2011) in the North precisely because it marks an attachment to security whose very condition of possibility no longer holds; in the South, in contrast, for the vast majority, vulnerability is shaped by temporal horizons both secular and spiritual that mark the "waxing and waning of life" itself (Singh 2015). Notions of risk and vulnerability resonate quite differently in contexts in which the liberal subject is absent.

Butler's notion of ontological precariousness, premised on the vulnerability that flows from the contingency of life itself and the social inter-dependence that necessarily and always underpins life, attempts to reconcile the dispossession of the sovereign subject with hierarchies of socio-economic dispossession; these hierarchies render some lives more precarious than others. Ontological precariousness, however, is an abstraction, trans-coded and constellated under distinct sociopolitical-cultural-religious-economic contexts in markedly distinct ways. Precariousness in its archaic (Latin) sense as 'subject to the will or decision of others,' or its contemporary Butlerian/Levinasian sense as dependence on others is the disavowed other within western liberal modernity. For many in non-western contexts, however, dependency is axiomatic to socio-cultural and economic life itself; "surplus populations," the apotheosis of unwaged precarious life deploy survival strategies that depend on the valuation of concrete modalities of social inter-dependence. Social interdependence, abstracted in Smithian, Hegelian, and Marxian accounts, but concretely disavowed in the life worlds of 'autonomous' individuals in liberal capitalist modernity, is recuperated in Butler's Levinasian telling as an ethical response to precarious life under conditions of neo/liberal modernity. In other times and places, however, social inter-dependence and the contingencies this entails are recognised as the condition of possibility of life itself. The life-worlds of precarious populations in the Global South are distinct not only in the obvious empirical sense but also in the ways that they escape enclosure by precarity's form, understood as a pathologized condition of dependence and vulnerability. Seen from this vantage point, vulnerability gains conceptual traction not as an (empty) universal, contra Butler, but as the spectre that haunts predominantly liberal accounts of autonomy, security and self-determined futurity in an intellectual and historical lineage that runs from Smith and Kant to Hegel and Marx. Neoliberalism's disavowal of social inter-dependence merely makes explicit this logic. That 'San Precario', the fictitious saint of the precarity movement (conjured up in 2004 in Italy) appears on bended knees with folded hands, a supplicant in prayer, dependent on 
(divine) will or the will of another, is a vivid reminder of the deep unease that accompanies overt social dependencies in western contexts; to be beholden to another a repudiation of the regulative ideal of autonomy, self-reliance and self-determination that is axiomatic to western liberal modernity.

To conclude, Butler attempts to suture a post-foundational account of the dispossessed subject to a global ethics based on recognition of a shared common vulnerability so as to mobilize a transformative politics against the unequal distribution of socio-economic precarity. By deploying a de facto quantified measure of vulnerability, however, Butler's account retains an unwitting affinity to a liberal analytic that, like Standing's, forecloses recognition of alterities within the domain of vulnerabilities as de-pathologized modes of life.

\section{Concluding Remarks}

"Any ontology of the present," Frederic Jameson notes, "needs to be an ideological analysis as well as a phenomenological description," and must be attentive to Koselleck's "description of historical temporalities" (Jameson 2015, 101-102). Later, and contrarily, he notes that with decolonization "subaltern others" are able to ".....speak in their own voice and claim their own existential freedom. Now, suddenly, the bourgeois subject is reduced to equality with all these former others, and a new kind of anonymity reigns throughout world society as a whole" (Jameson 2015, 129). "The emergence of the vulnerable subject into a world of billions of anonymous equals," (Jameson 2015, 130 ) is the definitive sign of the present. For Jameson too, it would appear, "we are all precarious now." Precarity and ontological precariousness, however, I have tried to show, offer a liberal not global analytic that depend on (1) the recuperation of abjection in the South as the locus of global precarity talk; and (2) mis-recognition of low consuming modes of life in the South as sites of material lack and abjection. Insofar as this is correct, how might we locate and apprehend the vulnerable subject in an ontology of the present, without resorting to either the flattening summoned by Jameson or the distinctions (without difference) enabled by liberal analytics? I can only gesture toward an alternative here.

The lived experience of qualitatively distinct de-pathologized vulnerabilities in the Global South can be brought into a global field of vision in the fullness of their alterities, only by escaping 'liberal capture' inherent to global precarity talk (indicatively, AlSayyad and Roy 2004; Roy 2011; Sanyal 2007; Sethi 2011; Singh 2015). Central to the flattening, quantifying compulsions of a liberal analytic is its temporal logic: secular, linear, moving only ever in one direction. To escape abjection by liberal 
analytics in the lived experience and phenomenology of 'precarity in the South,' subaltern ontological landscapes and the temporalities constitutive of them need to be made central to analysis. "I could not talk only about lack, even in a milieu of poverty," the anthropologist Bhrigupati Singh notes, "....and then gods and spirits beckoned me, since they, too, were part of this landscape" (Singh 2015, 9). Eschewing the binary framing of autonomy/dependency, sovereignty/precarity, security/insecurity that underpin theorizations of ontological precariousness and the subject of precarity in the North, vulnerabilities of life and living in the South may be better apprehended through an analytical strategy that takes seriously Koselleck's (2004) notion of multiple temporalities, or "non-contemporaneous contemporaneity" (Harootunian 2015). A positivist (mis)reading) of Dipesh Chakrabarty's claim in Provincializing Europe (2000) that the human is not ontologically singular, that "gods and spirits \{are\} existentially coeval with the human," has led unfortunately to the tendency to split the material from the spiritual/cultural in the so called 'ontological turn' (Descola 2013; 2017; Holbraard and Pedersen 2017) and claims about 'multiple ontologies' that, in the extreme, rehabilitate forms of cultural essentialism in themselves also highly problematic. However, Chakrabarty's 'time knots' can be effectively deployed to braid the secular, non-secular with the material to apprehend lives and modes of living otherwise. The "time knots" that permeate subaltern lives enable thicker forms of associations and socialities in which relations of dependency are not merely pre-ontic but central to everyday life in all its quotidian elements. Low consuming subalterns in the South do not seek the horizons of liberal sovereignty; neither are they, for that reason, abject. The protocols of quantified liberal thought, however, with its circumscribed vision of 'more-or-less' and its metrics of commensurability, foreclose recognition of depathologized vulnerabilities in the South. The universal logic of precarity as a disordering experience of liberal subjectivity breaks down in contexts where, for the vast majority of populations (in the South), life is lived otherwise. The de-pathologized thicker socialities and relations of mutual dependency that characterise life and living, especially for vulnerable populations in the South, impede the epistemic reach of precarity as a global analytic.

And what, finally, of Nirmalya? The protagonist of Amit Chaudhuri's novel, The Immortals whose decision to "choose precarity," Simon During suggests, is emblematic of the global condition of precarity, one in which the smoothed spaces of contemporary capitalism have rendered archaic distinctions between metropole and periphery, North and South? Nirmalya, the son of a middleclass family living in Bombay, is a music lover trained in classical singing by Shyam Lal whose work with his gifted mother, Mallika Sengupta, provides the main arc of the book's narrative. Committed to the mundane rather than the exceptional, Chaudhuri meticulously traces the everyday lives of two families in the Bombay of the 1970s and 80s. Towards the end of the book, Nirmalya departs 
India for England to study philosophy. "It is a jump out of India's modernising process," During notes, "into the heart of European modernity itself." More crucially, "it is a jump into - a choice - of a certain mode of precariousness" (During 2015, 35), that marks Nirmalya's entry “into interiorised Western subjectivity" (During 2015, 36). It is, I think, striking, that During tracks Nirmalya's precarity and precariousness to interiorised subjectivity, to European modernity, and his passage out from India to London, locating precarity/precariousness literally (and theoretically I have argued) in the North. In a passage on the penultimate page of the novel, however, comes another line that arguably reverses During's reading of the novel and captures, in spirit if not in letter, the line of argument I have been trying to pursue. Nirmalya: "Ah, the embrace of poverty! It was much less attractive here than it was at home; you felt the fight was going unnoticed, somehow" (Chaudhuri $2009,404)$. Why would the fight, we might ask, against poverty/precarity go unnoticed in London? Because poverty in the North is less than poverty in the South? Or because the liberal analytics of socio-economic precaritization and the flattening quantifications of thought they deploy render those in poverty unnoticeable in the North but, because thoroughly abject, noticeable in the South? Or is it because the fight against poverty in the South summons a different horizon of life and liveability, one in which expectations about security without struggle have no resonance. And one in which the fight itself in all its varied registers constitutes a fully human (de-pathologized) mode of life?

Symptomatic of the return of a new universalism, anchored in a tacit desire to re-ignite the 'utopian spark' (Zizek 2002, 310) of an internationalism rendered archaic in the post-1989 world, Standing and Butler's accounts of shared vulnerability as the condition of possibility for renewed political solidarities hold out the hope of a revived internationalism. Like species thinking, however, these attempts, anchored as they are in a specific notion of human life, namely liberal subjectivity and its security, unwittingly de-politicize. The difficult task of shunning the liberal subject or abandoning the desire to reconstitute its remains simply defers the forging of a politics, one that is attentive to historical difference.

\section{(Word Count 9713 without references)}

\section{References}

Alford, C. Fred (2002) "Emmanuel Levinas and Iris Murdoch: Ethics as Exit," Philosophy and Literature 26 (1): 24-42.

AlSayyad, Nezar (2004) "Urban Informality as a "New" way of life," in Ananya Roy and Nezar AlSayyad eds., Urban Informality: Transnational Perspectives from the Middle-East, Latin America, and South Asia. Lanham: Lexington Books, 7-30. 
Aravamudan, Srinivas (2012) "Surpassing the North: Can the Antipodean Avantgarde Trump Postcolonial Belatedness? The Salon 5: 1-4. http://www.jwtc.org.za/resources/docs/salon-volume5/Aravamudan.pdf (accessed 1 May 2018).

Barchiesi, Franco (2011) Precarious Liberation: Work, the State and Contested Social Citizenship in Postapartheid Africa. NY: State University of New York Press and University of Kwazulu-Natal.

Beck, Ulrich (2000) The Brave New World of Work. Cambridge: Polity Press.

Berlant, Lauren (2011) Cruel Optimism. Durham and London: Duke University Press.

Bernards, Nick (2018) The Global Governance of Precarity: Primitive Accumulation and the Politics of Irregular Work. London: Routledge.

Bhaba, Homi (1994) The Location of Culture. Oxford \& NY: Routledge.

Bourdieu, Pierre (1998) Acts of Resistance: Against the New Myths of Our Time. Cambridge: Cambridge University Press.

Bigo, Didier, and Walker, R.B.J. (2007) "Political Sociology and the Problem of the International," Millennium: Journal of International Studies 35 (3): 725-739.

Blaut, James M. (1993) The Colonizer's Model of the World. Geographical Diffusionism and Eurocentric History. New York/London: The Gilford Press.

Brass, Tom (2003) "Why Unfree Labour is not 'So-Called': The Fictions of Jairus Banaji," The Journal of Peasant Studies, 31 (1): 101-136.

Brass, Tom (2011) Labour Regime Change in the Twenty-first Century: Unfreedom, Capitalism and Primitive Accumulation. Leiden, Amsterdam: Brill.

Breman, Jan (2013) “A Bogus Concept?” New Left Review 84: 130-138.

Breman, Jan \& van der Linden, Marcel (2014) "Informalizing the Economic: the Return of the Social Question at a Global Level," Development and Change 45 (5): 920-940.

Burawoy, Michael (2009) "The Global Turn: Lessons from Southern Labor Scholars and their Labor Movements," Work and Opposition 36: 87-95.

Butler, Judith (2001) "On Giving an Account of Oneself," Diacritics 31 (4): 22-40.

Butler, Judith (2004) Precarious Life: The Powers of Mourning and Violence. London: Verso.

Butler, Judith (2005) On Giving an Account of Oneself. New York: Fordham University Press.

Butler, Judith (2009) Frames of War: When is Life Grievable? London, New York: Verso.

Butler, Judith (2015) Notes Toward a Performative Theory of Assembly. Cambridge: Harvard University Press.

Butler, Judith and Athanasiou, Athena (2013) Dispossession: The Performative in the Political. Cambridge, UK \& Malden, MA: Polity Press. 
Castels, Robert (2001) From Manual Workers to Wage Labour: Transformation of the Social Question, trans. by Richard Boyd. New Brunswick, N.J.: Transaction Publishers.

Chakrabarty, Dipesh (2000) Provincializing Europe: Postcolonial Thought and Historical Difference. Princeton, NJ: Princeton University Press.

Chambers, Samuel, and Carver, Terrell (2008) Judith Butler and Political Theory: Troubling Politics. Oxford and NY: Routledge.

Chaudhuri, Amit (2009) The Immortals. London: Picador.

Comaroff, Jean \& Comaroff, John L. (2012) Theory from the South: Or, how Euro-America is Evolving Toward Africa. NY: Paradigm Press.

Conell, Raewyn (2007) "The Northern Theory of Globalization," Sociological Theory 25(4): 368-385).

Descola, Philippe (2013) Beyond Nature and Culture, trans. by Janet Lloyd. Chicago \& London: University of Chicago Press.

Descola, Philippe (2017) 'The Ontology of Others: An Interview with Philippe Descola' Ponto de vista. https://pontodevistaenglish.wordpress.com/2017/07/30/the-ontology-of-others-an-interviewwith-philippe-descola/ (accessed 12 July 2018).

Doogan, Kevin (2009) New Capitalism? The Transformation of Work. London: Polity Press.

Drabinski, John E. (2011) Levinas and the Postcolonial: Race, Nation, Other. Edinburgh: Edinburgh University Press.

During, Simon (2015) “Choosing Precarity," South-Asia: Journal of South Asian Studies 38 (1): 19-38.

Ettlinger, Nancy (2007) “Precarity Unbound," Alternatives: Global, Local, Political 32 (3): 319-340.

Fabian, Johannes (1983) Time and the Other: How Anthropology Makes its Object. NY: Columbia University Press.

Foti, Alex (2017) "General Theory of the Precariat: The Great Recession, Revolution, Reaction," Theory on Demand\#25 http://networkcultures.org/blog/publication/general-theory-of-theprecariat/ (accessed 14 November 2018).

Gilson, Erinn C. (2014) The Ethics of Vulnerability: A Feminist Analysis of Social Life and Practice. New York: Routledge.

Gregory, Derek (2004 The Colonial Present. Malden,MA: Blackwell.

Han, Clara (2018) "Precariousness, Precarity and Vulnerability," Annual Review of Anthropology 47 (1): 331-343.

Hardt, Michael \& Negri, Antonio (2004) Multitude: War and Democracy in the Age of Empire. New York: Penguin Press.

Hardt. Michael (1999) “Affective Labor,” boundary 226 (2): 89-100. 
Harootunian, Harry (2015) Marx After Marx: History and Time in the Expansion of Capitalism. NY: Columbia University Press.

Harvey, David (1982) The Limits to Capital. Oxford: Basil Blackwell.

Harvey, David (2004) "The New Imperialism: Accumulation by Dispossession," Socialist Register 64: 63-87.

Hegel, G.W.F. (\{1820\} 1991) Elements of the Philosophy of Right, trans. by Allen W. Wood.

Cambridge: Cambridge University Press.

Holbraad, Martin \& Pedersen, Morten Axel (2017) The Ontological Turn: An Anthropological Exposition. Cambridge: Cambridge University Press.

Huffington, Arianna (2010) Third World America: How Our Politicians are Abandoning the MiddleClass and Betraying the American Dream. NY: Crown.

International Labour Organization (2018) Women and Men in the Informal Economy: A Statistical Picture (Geneva).

International Labour Organization (2016) Non-standard Employment Around the World:

Understanding Challenge, Shaping Prospects

https://www.ilo.org/global/publications/books/WCMS 534326/lang--en/index.htm (Accessed 25 June 2018).

Jameson, Frederic (2015) “The Aesthetics of Singularity," New Left Review 92 (March-April): 101-132.

Jameson, Fredric (2003) “The End of Temporality," Critical Inquiry 29 (4): 695-718.

Jørgensen, Martin Bak (2016) “Precariat- What it Is and Isn't- Towards an Understanding of What it Does," Critical Sociology 42 (7-8): 959-974.

Koselleck, Reinhart (2004) Futures Past: On the Semantics of Historical Time. NY: Columbia University Press.

Kristeva, Julia (1982) Powers of Horror: An Essay on Abjection, trans. by Leon. S. Roudiez. NY: Columbia University Press.

Lawn, Jennifer (2017) "Precarity: A Short Literary History, from the Colonial Slum to the Cosmopolitan Precariat," Interventions 19 (7): 1-15.

Lazzarato, Maurizio (2017) Experimental Politics: Work, Welfare and Creativity in the Neoliberal Age trans. Arranna Bove et. al. ed. Jeremy Gilbert. Cambridge, MA and London, England: MIT Press.

Llewelyn, John (1995) Emmanuel Levinas: The Genealogy of Ethics. London: Routledge.

Lemke, Sieglinde (2016) Inequality, Poverty and Precarity in Contemporary American Culture. NY:

Palgrave, Macmillan.

Levinas, Emmanuel (1998) Otherwise than Being: Or Beyond Essence trans. by Alphonso Lingis. Pittsburgh: Duquesne University Press. 
Lloyd, Moya (ed.) (2015) Butler and Ethics. Edinburgh: Edinburgh University Press.

Lorey, Isabell (2011) “Government Precarization,” http://eipcp.net/transversal/0811/lorey/en (accessed 10 August, 2018).

Lorey, Isabell (2015) State of Insecurity: Government of the Precarious, trans. by Aileen Derieg. London: Verso.

Membe, Achille (2010) On the Postcolony. LA: University of California Press.

Migration Policy Institute https://www.migrationpolicy.org/programs/data-hub/internationalmigration-statistics (accessed 15 June 2018).

Milbank, John and Pabst, Adrian (2015) "The Meta-Crisis of Secular Capitalism," International Review of Economics 62: 197-212.

Millar, Kathleen (2014) "The Precarious Present: Wageless Labour and Disrupted Life in Rio de Janeiro, Brazil," Cultural Anthropology 29 (1): 32-53.

Mills, Catherine (2007) "Norm Violation Vulnerability and Responsibility," differences, A Journal of Feminist Cultural Studies 18: 133-156.

Mills, Catherine (2015) "Undoing Ethics: Butler on Precarity, Opacity and Responsibility," in Moya Llyod eds. Butler and Ethics. Edinburgh: Edinburgh University Press.

Munck, Ronaldo (2013) "The Precariat: a View from the South," Third World Quarterly 34 (5): 747762.

Nandy, Ashis (2001) An Ambiguous Journey to the City: The Village and Other Odd Ruins of the Self in the Indian Imagination. New Delhi: Oxford University Press.

Nandy, Ashis (2002) "The Beautiful, Expanding Future of Poverty: Popular Economics as a Psychological Defense," International Studies Review 4 (2): 107-121.

Neilson, Brett \& Rossiter, Ned (2008) "Precarity as a Political Concept, or, Fordism as Exception," Theory Culture Society 25(7-8) pp. 51-72.

Nixon, Rob (2011) Slow Violence and the Environmentalism of the Poor. Cambridge, MA.: Harvard University Press.

Ortner, Sherry (2016) "Dark Anthropology and its Others: Theory since the '80s," Journal of Ethnographic Theory 6 (1): 47-73.

Perelman, Michael (2000) The Invention of Capitalism, Classical Political Economy and the Secret History of Primitive Accumulation. Durham: Durham University Press.

Pang, Irene (2018) "The Legal Construction of Precarity: Lessons from the Construction Sectors in Beijing and Delhi," Critical Sociology (September).

Perlman, Janice E. (1976) The Myth of Marginality: Urban Poverty in Rio de Janeiro. Berkeley, CA: University of California Press. 
Polanyi, Karl (1957) The Great Transformation; The Political and Economic Origins of Our Time. Boston: Beacon.

Povinelli, Elizabeth (2011) Economies of Abandonment: Social Belonging and Endurance in Late Liberalism. Durham, N.C.: Duke University Press.

Puar, Jasbir (ed.) (2012) "Precarity talk: A Virtual Roundtable with Lauren Berlant, Judith Butler, Bojana Cvejić, Isabell Lorey, Jasbir Puar, and Ana Vujanović,” TDR: The Drama Review 56 (4): 163177.

Read, Jason (2002) "Primitive Accumulation: the Aleatory Foundation of Capitalism," Rethinking Marxism 14 (2): 24-49.

Roy, Ananya (2011) "Slumdog Cities: Rethinking Subaltern Urbanism," International Journal of Urban and Regional Research 35 (2): 223-238.

Saddler, Sarah (2017) “'Think Differently, Get Creative': Producing Precarity in India's Corporate Theatre Culture Industry," Research in Drama Education: The Journal of Applied Theatre and Performance 22 (1): 22-35.

Sanyal, Kalyan (2007) Rethinking Capitalist Development: Primitive Accumulation, Governmentality and Post-Colonial Capitalism. New Delhi: Routledge India.

Sassen, Saskia (2014) Expulsions: Brutality and Complexity in the Global Economy. Cambridge, MA.: Belknap Press.

Scully, Ben (2016) "Precarity North and South: A Southern Critique of Guy Standing," Global Labour Journal 7(2): 16-173.

Sethi, Aman (2011) A Free Man: A True Story of Life and Death in India. Delhi: Random House.

Seymour, Richard (2012) "We Are All Precarious - On the concept of the "Precariat" and its Misuses," New Left Project.

http://www.newleftproject.org/index.php/site/article comments/we are all precarious on the concept of the precariat and its misuses (accessed 21 June 2018).

Singh, Bhrigupati (2015) Poverty and the Quest for Life: Spiritual and Material Striving in Rural India. Chicago: University of Chicago Press.

Sloterdjik, Peter (2013) In the World Interior of Capital: Towards a Philosophical Theory of Globalization. Cambridge, UK \& Malden, MA: Polity Press.

Standing, Guy (2011) The Precariat: The New Dangerous Class. London \& NY: Bloomsbury.

Standing, Guy (2012) “The Precariat: from Denizens to Citizens?” Polity 44 (4): 588-608.

Standing, Guy (2013) “Where's Howard?” Global Discourse 3 (3-4): 546-553.

Standing, Guy (2014) A Precariat Charter: From Denizens to Citizens. London \& NY: Bloomsbury. 
Standing, Guy (2016) "Meet the Precariat, the New Global Class Fuelling the Rise of Populism," https://weforum.org/agenda/11/precariat-gloabl-class-rise-of-populism/ (accessed 12 June 2018).

Trott, Ben (2014) "From the Precariat to the Multitude," Global Discourse 29: 1-20.

Tsantsoulas, Tiffany N. (2018) “Sylvia Wynter's Decolonial Rejoinder to Judith Butler's Ethics of Vulnerability," Symposium 22 (2): 158-177.

Van der Linden, Marcel (2014) "San Precario: A New Inspiration for Labor Historians," Labor Studies in Working-Class History of the Americas 11 (1): 9-21.

Van der Linden, Marcel, and Roth, Karl Heinz (2014) Beyond Marx: The Global Labour Relations of the $21^{\text {st }}$ Century. Leiden: Brill.

Walker, R.B.J. (1997) "The Subject of Security," in Keith Krause and Michael C. Williams eds., Critical Security Studies: Concepts and Cases. Minnesota: University of Minnesota Press, 61-82.

Wacquant, Loïc (2007) "Territorial Stigmatization in the Age of advanced Marginality," Thesis Eleven 91 (1): 72-73.

Waite, Louise (2009) "A Place and Space for a Critical Geography of Precarity?" Geography Compass $3(1): 412-433$.

Weeks, Kathi (2011) The Problem with Work: Feminism, Antiwork Politics, and Postwork Imaginaries. Durham and London: Duke University Press.

White, Stephen K. (1999) “As the World Turns: Ontology and Politics in Judith Butler," Polity 42 (2): 155-177.

Žižek, Slavoj (2002) Revolution at the Gates: Selected Writings of Lenin From 1917. London: Verso.

\footnotetext{
${ }^{1}$ For discussion and lively debate around a very early iteration of this project, my thanks to students in my seminar at PUC-Rio - Pontifical Catholic University of Rio de Janeiro, and to Joăo Nogueira for extending the invitation.

2 Julia Kristeva's concept of abjection is a psychoanalytic one that tracks the mechanisms of revulsion and disgust that disrupt the subject's sense of subject-object distinctions. Within some traditions of thought in political-economy, (including what I refer to as the liberal analytic in this paper), the characterisation of people in extreme poverty/precarity as "servile, wretched, contemptible" (Webster's dictionary meaning of abjection), worthy of revulsion and disgust merits the use of Kristeva's concept albeit in a different register. ${ }^{3}$ For good overviews of 'precarity studies' see especially Castels 2001; Han 2018; Jørgensen 2016; Lemke 2016; Millar 2014; Seymour 2012; and Trott 2014..

${ }^{4}$ Post-foundational conceptualizations of the subject use the language of non-sovereignty to signal a critique of the Enlightenment notion of a unitary subject. Non-sovereignty, however, can also be deployed in a postcolonial register where the liberal subject of autonomous self-mastery is simply not the dominant ideal.

${ }^{5}$ I take the term 'precarity talk' from the virtual roundtable discussion edited by Jasbir Puar (2012).

${ }^{6}$ See especially, Ronald Munck 2013; Standing 2013, and Scully 2016.
} 


\footnotetext{
${ }^{7}$ Robert Castels points out that wage labour was seen as a sign of dependency, not freedom, for a long time in western modernity. Projecting these disavowed elements to the "savage slot" rendered the Third World the locus of dependency and unfreedom.

${ }^{8}$ Standing's work in promoting Universal Basic Income and cash transfers across many countries also contributes to the common sense that precarity is a global concept.

${ }^{9}$ Julia Kristeva explains abjection as "a something I do not recognize as a thing" (Kristeva 1982).

${ }^{10}$ That Levinas also works with an idea of Europe that "blocks any easy engagement across geographies"

(Drabinski 2011,2 ) is also problematic for any attempt to globalize Levinasian thought. In a closely argued but nevertheless sympathetic engagement with Levinas, Drabinski points out that Levinas remains tied to a "metaphysics and so also a kind of epistemology of alterity," both of which blocks his thinking from the "sorts of geographical wanderings with which it ought to be engaged" (Drabinski 2011, 3).
} 